This article has been published in a revised form in Church History https://doi.org/10.1017/S0009640721002122. This version is published under a Creative Commons CC-BY-NC-ND. No commercial re-distribution or re-use allowed. Derivative works cannot be distributed. (C) copyright holder.

\title{
Parish politics and godly agitation in late Interregnum Scotland
}

\section{Chris R. Langley}

11,606 words with notes

10,128 words without notes 
The Kirk of Scotland was divided following the English invasion in July 1650 and the coronation of Charles Stuart as King of Scotland at Scone in 1651. Uncomfortable with the concessions made to Charles II and his supporters, a minority of ministers within the Kirk petitioned aggressively for the country to change course or risk the wrath of God. At a meeting of the General Assembly at St Andrews in 1651, the Assembly leadership moved to eject the ringleaders of the petitioning campaign and refused to admit them to the Assembly. The ejected ministers protested quickly against what they considered to be blatant gerrymandering of the Assembly's membership and refused to acknowledge the Assembly as a legitimate meeting. In the months that followed, pockets of Protester agitation emerged across the country with notable concentrations in the presbyteries of the north east and south west, areas in which Protesting ministers would attend local presbytery meetings but reject most of the acts passed by their colleagues. ${ }^{1}$ In a more extreme example, ministers in Linlithgowshire created a separate, 'protesting', presbytery that met away from its 'Resolutioner' counterpart. The separate presbytery made decisions relating to vacant parishes in the region, trained expectant ministers and attempted to persuade other clerics in the region to join their cause. Efforts to unite the factions were usually acrimonious and accompanied by aggressive and lengthy polemical exchanges.

The extent to which the Protesters separated from the Kirk is a matter of some debate. ${ }^{2}$ Writing in 1972, Gordon Donaldson observed how the Protesters' actions 'puzzled' both contemporaries and later historians as they somehow 'managed to pay lip-service to Presbyterianism' but refused to 'formally renounce its principles', despite apparently ignoring them in practice. ${ }^{3}$ Prominent protesters like Samuel Rutherford rejected any imputation that they were inclined to separatism but continued to inhabit 'an unhappy halfway house' that urged the importance of rooting out pollution within the established Church while continuing to condemn some of the activities of that same Church. ${ }^{4}$ Such ideas had a long history and created a 'deep and ineffaceable theological tension' in the Reformed Kirk of Scotland. ${ }^{5}$ Fissures between moderate and radical Presbyterians have led some

\footnotetext{
1 Frances Dow, Cromwellian Scotland, $1651-60$ (Edinburgh, 1979); Stevenson, Revolution and CounterRevolution in Scotland, 1644-51 (London, 1977); R. Scott Spurlock, Cromwell and Scotland: Conquest and Religion, 1650-1660 (Edinburgh, 2007).

2 David Stevenson, 'Conventicles in the Kirk, 1619-37. The emergence of a radical party', Records of the Scottish Church History Society, 18 (1973), 114.

${ }^{3}$ Gordon Donaldson, 'The emergence of schism in seventeenth-century Scotland', Studies in Church History, 9 (1972), 288.

${ }^{4}$ John Coffey, Politics, Religion and the British Revolutions: The Mind of Samuel Rutherford (Cambridge, 1997), 220-2.

${ }^{5}$ David George Mullan, Scottish Puritanism, 1590-1638 (Oxford, 2000), 131.
} 
historians to consider how the covenanting movement managed to remain relatively united for so long. ${ }^{6}$

Pushed to its most radical extreme, this tension could tip a very small minority of radical Scottish Presbyterians towards the kinds of Independency seen in England after the outbreak of war in 1642. Following the painstaking work of Hunter Powell, we now appreciate that some of the Scottish Commissioners at the Westminster Assembly of Divines held a degree of affinity with English separatists regarding the power of individual congregations although none moved formally in that direction. ${ }^{7}$ Similarly, a fringe of Protesting ministers, moved by the same kinds of discussions, raised the possibility of seceding from the Kirk in late 1652, although this may have been to strengthen their hand in negotiations with Resolutioners. ${ }^{8}$ In other areas, such speculation led to more tangible splits from the Kirk, such as the well-known case of the Aberdeen Independents led by former provost Alexander Jaffray and minister George Menzies. Less prominent groups emerged in East Kilbride. ${ }^{9}$ Many of these individuals eventually converted to become Baptists or Quakers as part of a similar spiritual journey to radicals in England during the 1640s and '50s. Much of this work has shown how Scottish Protestants were not immune to the effects of what one scholar called 'sectarian Puritanism' and its tendency to separate. ${ }^{10}$

It is this article's contention that the numbers of Scots who formally separated from the established Church in the middle of the seventeenth century has been exaggerated, leading scholars to overlook how commitment to the idea of a national church was a defining characteristic of all but the most radical Presbyterian communities. Historians looking elsewhere in Britain and Ireland continue to appreciate the centrality of the idea of the ecclesia mixta to Presbyterians. In arguing against New England congregationalists, for example, English Presbyterians stressed the presence of universal, rather than particular or gathered, churches in the Old Testament and opposed autonomy of particular

\footnotetext{
${ }^{6}$ Alexander D. Campbell, The Life and Works of Robert Baillie (1602-1662): Politics, Religion and RecordKeeping in the British Civil Wars (Woodbridge, 2017), 167.

${ }^{7}$ Hunter Powell, The Crisis of British Protestantism: Church Power in the Puritan Revolution, 1638-1644 (Manchester, 2015), 35-60.

${ }^{8}$ Kyle D. Holfelder, 'Factionalism in the Kirk during the Cromwellian invasion and occupation of Scotland, 1650 to 1660: The Protester-Resolutioner controversy', unpublished PhD thesis (University of Edinburgh, 1998), 101-3.

${ }^{9}$ R. Scott Spurlock, “'Anie gospell way”: Religious diversity in Interregnum Scotland', Records of the Scottish Church History Society, 32 (2007), 89-119; R. Scott Spurlock, Cromwell and Scotland: Conquest and Religion 1650-1660 (Edinburgh, 2007), 198-9.

${ }^{10}$ David R. Como, 'Radical Puritanism', in John Coffey \& Paul C. H. Lim (eds), The Cambridge Companion to Puritanism (Cambridge, 2008), 252.
} 
congregations. ${ }^{11}$ English Presbyterian classes continued to operate under the government's policy of freedom of conscience, ordaining new ministers and providing important forms of pastoral support to parishioners. ${ }^{12}$ At no stage did Presbyterians elsewhere in Britain and Ireland notionally or actually secede from their established national Church of origin. Rather, factions within Presbyterian congregations debated who should lead the Church - a minority godly elite or a broad-based hierarchy that ran the risk of spiritual pollution. If historians are indeed magpies as John Morrill has suggested, historians of Scotland may be guilty of focusing too much on the small number of eye-catching acts by those who separated from the Kirk, rather than appreciating how commitment to a national Church reveals far bigger questions about how a Church should be reformed and who should do it. ${ }^{13}$ While very recent work has started to appreciate the significance of the national Church idea to Scottish Protestants, we have yet to understand how this worked in practice. ${ }^{14}$

The historiographical focus on separation stems from an acceptance of Resolutioner polemic that has served to mask a well-organised godly coalition that sought to work within existing structures of ecclesiastical and civil law to bring about reform in the Kirk. They positioned themselves as the rightful, minority, government of the Kirk. While they protested against the legality of the 1652 General Assembly and reject any overtures related to it, they continued to operate within the Kirk. They showed their commitment to one national Church and abhorrence of separatism by working through established procedures within the Kirk, attending church meetings, accepting due process and refusing to jump ship to form a new church altogether. Constant agitation did not necessarily equate to a desire to secede from the structures of the established Church. On the contrary: it reflected a deep commitment to the idea of a single, national ecclesiastical body.

One particular bloc of Protester influence that centred on Midlothian forms the focus of this article. A highly organised group of lay and clerical figures, the Midlothian Protesters

\footnotetext{
${ }^{11}$ Donald F. Chatfield, 'The congregationalism of New England and its repercussions in England and Scotland 1641-1662', unpublished PhD thesis (University go Edinburgh, 1963), 99-100; Ann Hughes, 'Inside and outside the national church', 94.

12 Ann Hughes, 'Popular Presbyterianism in the 1640s and 1650s: The cases of Thomas Edwards and Thomas Hall', in N. Tyacke (ed.), England's Long Reformation, 1500-1800 (London, 1998); Elliot Vernon, 'A ministry of the gospel: The Presbyterians during the English Revolution', in Chris Durston \& Judith Maltby (eds), Religion in Revolutionary England (Manchester, 2006); The Minutes of the Antrim Ministers' Meeting, 1654-8, ed. Mark Sweetnam (Dublin, 2012).

${ }^{13}$ John Morrill, 'The Church in England, 1642-9', in John Morrill (ed.), Reactions to the English Civil War 1642-1649 (London, 1983), 90.

${ }^{14}$ R. Scott Spurlock, 'Boundaries of Scottish Reformed orthodoxy, 1560-1700', in David Fergusson, Mark W. Elliott (eds.), The History of Scottish Theology, 1 (Oxford, 2019), 359-76.
} 
had considerable knowledge of contemporary legal procedures in both civil and ecclesiastical courts. Their understanding of the intricacies of legal practice combined with their desire to reform the ministry of the Church to produce aggressive, highly litigious and targeted campaigns against local ministers. In focusing on the parish of Crichton in Midlothian, this article will reveal a hitherto underappreciated group of protesting Presbyterian lobbyists who used civil and ecclesiastical weaponry to forcibly reform the parish ministry in their area of influence.

Midlothian's godly network left behind a substantial paper trail, especially pertaining to their activities in and around the parish of Crichton. The litigious culture of Crichton's parish elites spanned both civil and ecclesiastical courts, much of which survives in the documentary record. While Crichton lacks the kirk session records that historians such as Margo Todd have used so effectively to add texture to the religious experiences of earlymodern parishioners elsewhere in Scotland, the survival of documents from the surrounding jurisdictions of Dalkeith Presbytery and the Synod of Lothian and Tweeddale (including lengthy committee reports) allow historians to piece together the voluminous disputes emanating from the parish brought before the ecclesiastical courts. ${ }^{15}$ Crichton's disputes are also illuminated by the survival of a number of relevant civil court records, particularly the Register of Deeds of the Court of Session and papers relating to parish finance disputes, that all involved the same Protester participants as those processes heard before the ecclesiastical courts. Finally, the diary of one prominent member of the Protester network, largely overlooked in other studies of the period, shows how the Protesters orchestrated attacks across civil and ecclesiastical jurisdictions. This corpus of documents provides the first insight into Protester agitation at the parish level and a more refined view of the manner in which Protesters - and other interest groups - attempted to influence parish politics away from the printing press, without seceding altogether from the structures of their national Church.

\section{Parish Politics}

The rural parish of Crichton sits fourteen miles south east of Edinburgh and is situated in Midlothian on the east bank of the River Tyne. Established in the late-medieval period as a collegiate foundation, Crichton grew from around three hundred communicants in 1627 to

\footnotetext{
${ }^{15}$ Margo Todd, The Culture of Protestantism in Early Modern Scotland (New Haven, 2002).
} 
more than five hundred in the 1640s. ${ }^{16}$ In recognition of this growth, an act of Parliament officially recognised the settlement as a parish in its own right in November 1641. Due to its collegiate heritage, very little of the land that funded the minister's stipend actually sat within the bounds of the parish and was instead scattered across Midlothian. The various prebendaries and heritable possessions established to support the clerics of the medieval period formed a checkerboard of local interests ranging from land belonging to the old parish church attached to the Castle, the three prebendaries of Middleton and Arniston to the south and the Prebendary of Vogrie to the north. ${ }^{17}$ As a former collegiate foundation, the minister was appointed by a provost and by the seventeenth century this responsibility lay in the hands of the Scotts of Buccleuch - usually the Earl's brother. The Scotts, however, were not the only significant family with an interest in Crichton and the lands that surrounded it. The masters of the Castle - the Hepburns of Humbie - controlled just under half the rents that funded the minister's stipend derived from their ownership of the fertile lands on the west bank of the river, the Borthwicks of Sauchnell controlled another quarter with the remaining rents raised from lands belonging to a range of landowners including the Earl of Lauderdale. ${ }^{18}$ Numerous other landowners contributed small amounts of grain and victual to the minister's maintenance, including the Wauchops of Cakemuir. While most parishes had more than one heritor - making collecting the stipend difficult - the distribution of teindpaying land between so many significant local power brokers across the region was quite unique. $^{19}$

The parish minister was at the centre of this complex web of relationships in Crichton and the wider region through kinship, marriage and land ownership. Prior to its establishment as a parish church in 1641, the parochial duties of the ministry were overseen by William Penman, a sexagenarian, educated at St Andrews in the later part of the sixteenth century. Three of his four sons entered the ministry in neighbouring parishes. By May 1639, Penman's 'age and infirmitie' forced him to ask authorities whether his son, Gideon, might be admitted as his assistant, a request that his parishioners accepted in June of the same

\footnotetext{
${ }^{16}$ NRS, CH2/424/3, ff. 264-5; The Old Statistical Account of Scotland, 14 (Edinburgh, 1795), 433-7.

${ }^{17}$ Ian B. Cowan, The Parishes of Medieval Scotland (Edinburgh, 1967), iii-v; Registrum Magni Sigilli Regum Scotorum, vi, ed. John Maitland Thomson (Edinburgh, 1890), 145; Reports on the State of Certain Parishes in Scotland, 1627, ed. Alexander MacGrigor (Edinburgh, 1835), 54-7.

${ }^{18}$ NLS, TE5/161, item 2.

19 Walter R. Foster, 'A constant platt achieved: Provision for the ministry, 1600-38', in Duncan Shaw (ed.), Reformation and Revolution: Essays Presented to the Very Reverend Principal Emeritus Hugh Watt (Edinburgh, 1967), 135; Alan R. MacDonald, 'Teinds and stipends in seventeenth-century Linlithgowshire', unpublished conference paper presented at the 'Agriculture and teind reform in early modern Scotland', University of Edinburgh, May 2017.
} 
year. ${ }^{20}$ Both men served the parish, with Gideon attending presbytery meetings on his father's behalf and with the pair of them signing the National Covenant alongside their neighbours in 1638. Despite one parish history asserting that William was deposed, he was still serving the cure with his son in 1642 and probably demitted his post shortly after. ${ }^{21}$ The Penmans were increasingly ensconced in the affairs of the local landowning classes, holding rights to lands nearby and even contributing teinds to the ministry of neighbouring Borthwick. ${ }^{22}$ Gideon Penman's first marriage to Martha Scott gave the minister a connection to his patrons, the Scotts of Buccleuch, and provided rights to more tracts of land in the Hagbrae part of the parish. Following Martha's death, Penman married his second wife, Jean, who was daughter of William Livingston, the godly minister of Lanark. ${ }^{23}$

The first decade of Penman's ministry coincided with a turbulent period of civil war but his time in Crichton seems to have been unremarkable. Penman was a growing presence in local ecclesiastical business and was present when ministers from across the region returned their resubscribed copies of the National Covenant in November $1643 .{ }^{24} \mathrm{He}$ submitted one that was fully endorsed. His peers in the Presbytery trusted him to do occasional errands such as the survey of the boundaries of the newly-formed Presbytery of Biggar in 1642 and delivering the Presbytery's charitable contribution to James Mirk, a Protestant minister fleeing Catholic rebels in Ireland. ${ }^{25}$ Colleagues approved all the sermons he preached before them throughout his career and they chose to send him as one of the Presbytery's commissioners to the General Assembly in $1644 .{ }^{26}$ His attendance at Presbytery meetings was average with a handful of absences because of ill health. Based on appearances in the records of Dalkeith Presbytery and the Synod of Lothian and Tweeddale, Gideon Penman was like so many of the names that litter mid-seventeenth-century records: an unknown quantity who quietly existed through the biggest political upheavals of his lifetime.

A closer look into the non-ecclesiastical records of parish life in Crichton reveals a slightly different picture in which Penman struggled to navigate the parish's complex of interests. ${ }^{27}$ In 1640, a feud erupted between the Wauchops of Cakemuir and the Borthwicks

\footnotetext{
${ }^{20} \mathrm{NRS}, \mathrm{CH} 2 / 424 / 2$, ff. 137-8.

${ }^{21}$ John Dickson, Crichtoun, Past and Present (Edinburgh, 1911), 70-1.

${ }^{22}$ NRS, CH2/424/3, f. 46.

${ }^{23}$ Scott, Fasti, i, 312; John Nicoll, A Diary of Public Transactions and Other Occurrences Chiefly in Scotland, ed. David Laing (Edinburgh, 1826), 434.

${ }^{24} \mathrm{NRS}, \mathrm{CH} 2 / 424 / 3$, f. 111.

${ }^{25}$ NRS, CH2/424/3, f. 96.

${ }^{26} \mathrm{NRS}, \mathrm{CH} 2 / 424 / 3$, ff. 118-19.

${ }^{27}$ Some of these disputes echo much older arguments over the parish stipend. My thanks to Dr Norah Carlin for sharing her unpublished work on teinds in Midlothian.
} 
of Sauchnell, with the latter claiming the Cakemuirs held them in 'malice and invy' and had deliberately inflated the value of Church lands in Sauchnell. ${ }^{28}$ Penman was personally involved in a dispute over the collection of teinds in 1642 that led to litigation with one of his heritors. ${ }^{29}$ The consequences of these disputes were twofold: the parish, despite having a grammar school and separate music school, did not have a local schoolmaster or reader and the church building required considerable repair that had evidently been sidelined during the disputes. ${ }^{30}$ The Presbytery of Dalkeith intervened in April 1642 and ordered that the local landowners contribute, proportionally, to the repair of the church. Borthwick and Cakemuir were appointed to collect the money and agree to a schedule of works with local craftsmen and labourers. ${ }^{31}$ Despite such local animosities, the elders told a visitation of the parish in 1649 that they were 'aboundantlie satisfied' with their minister and 'knew nothing they would have him admonished off'. Penman, for his part, reported that the schoolmaster's stipend was still inadequate and asked that his elders be 'exhorted to pietie and sobrietie'. ${ }^{32}$

Penman's ability to hold together the checkerboard of interests converging in his parish came to an abrupt end in 1654. He reported to colleagues in the Presbytery of Dalkeith that he was 'overswayed' with a 'grosse scandell' involving two members of his kirk session. ${ }^{33}$ The feud centred on the parish schoolmaster, precentor and session clerk, James Bartrum, and John Gilchrist an elder on the parish kirk session and chamberlain to Adam Hepburn, Lord Humbie, master of Crichton Castle. As Bartrum rode through a part of the parish, he observed Gilchrist collecting divots of grass (a cheap source of fuel). Bartrum jumped from his passing cart and shouted that Gilchrist would hang if he continued taking what he thought, as schoolmaster and reader, was rightfully his. Before Bartrum's wife could restrain him, he shouted that Gilchrist was 'ane jew, ane reprobate, not worthie to be ane elder but mor meet to be a sow libber', while Gilchrist rejected Bartrum's complaints by uttering 'tish tash of Christ' ${ }^{34}$ While Gilchrist was eventually convicted of blasphemy, the case raised questions about Penman's ability to negotiate with groups in his congregation. Gilchrist accused Penman of partiality and fabricating the claims against him.At one stage, his master, Adam Hepburn of Humbie, became involved in investigating Penman's conduct.

\footnotetext{
${ }^{28}$ NRS, RH15/29/163, not paginated.

${ }^{29}$ NRS, GD1/1120/9, not paginated.

30 John Durkan, Scottish Schools and Schoolmasters 1560-1633, ed. Jamie Reid Baxter (London: Scottish History Society, 2013), 165-6; 260.

${ }^{31}$ NRS, CH2/424/3, f. 87.

${ }^{32}$ NRS, CH2/424/3, ff. 344-5.

${ }^{33} \mathrm{NRS}, \mathrm{CH} 2 / 424 / 4$, f. 163.

${ }^{34}$ NRS, CH2/424/4, ff. 169-71.
} 
Neighbouring ministers in the region reported how there was 'som differance in the session' and it was 'liklie that ther might aryse som mair therabout' if not dealt with circumspectly. ${ }^{35}$ While lay involvement in kirk sessions gave them incredible strength in understanding the daily lives of their neighbours, it also made them prone to factional disputes that could boil over in the most public of settings. ${ }^{36}$

Ministers' abilities to settle disputes were highly valued but the ideal of harmonious relationships between cleric and his flock was not always the reality. ${ }^{37}$ Penman's conduct in the aftermath of the very public dispute between two of his elders served to inflame tensions with godly members of his congregation. Penman reported to the Presbytery that he had suspended one of the most prominent elders of the parish, Andrew Borthwick of Sauchnell, for using his influence on the parish session to protect his family's reputation. In response, Borthwick angrily criticised the minister and swore "that he wold never sit againe in that session ${ }^{38}$ Ministers from across the Presbytery conferred with Borthwick in private, requiring the concurrence of such a powerful local magnate, and upon returning, he apologised for his conduct and accepted his suspension. ${ }^{39}$ The following summer, Penman moved to suspend the schoolmaster and reader James Bartrum following his part in the Gilchrist case. Bartrum successfully appealed to the Presbytery, mirroring the language John Gilchrist had used in his accusations against Penman the previous year. After a period of ill health, Penman retaliated in October by accusing Bartrum and David Wilson, another elder on the session, of committing fornication with a local woman named Isobel Hislop. Hislop had confessed, claiming the two men, earlier in the year, had tied her in the snow and raped her. While this was enough to move Penman and the session in Crichton to suspend Wilson, Hislop's testimony was discredited by the ministers present at the Presbytery meeting who described her as 'non compis mentis'. ${ }^{40}$ Penman was forced to reinstate Wilson, 'long ane man of ane good report', and apologise for his own hasty conduct. Penman would not relent in his pursuit of his former schoolmaster, however, and reported that Bartrum had told him

\footnotetext{
${ }^{35} \mathrm{NRS}, \mathrm{CH} 2 / 424 / 4$, f. 164.

${ }^{36}$ Margo Todd, 'Consistories', in Charles H. Parker \& Gretchen Starr-Lebeau (eds), Judging Faith, Punishing Sin: Inquisitions and Consistories in the Early Modern World (Cambridge, 2017), 41.

${ }^{37}$ John Bossy, Christianity in the West 1400-1700 (Cambridge, 1985); Neal Enssle, 'Patterns of godly life: The life parish minister in sixteenth- and seventeenth-century English thought', Sixteenth Century Journal, 28 (1997), 24-5; Mullan, Scottish Puritanism, 70-1.

${ }^{38} \mathrm{NRS}, \mathrm{CH} 2 / 424 / 4$, ff. 172, 175-6.

${ }^{39}$ Michael F. Graham, Uses of Reform: 'Godly Discipline' and Popular Behavior in Scotland and Beyond, 1560-1610 (Leiden, 1996), 348.

${ }^{40} \mathrm{NRS}, \mathrm{CH} 2 / 424 / 4$, f. 274.
} 
that 'the Curse of God cannot but come upon him' and that the minister was a 'seditious man'. ${ }^{41}$

Bartrum escalated his dispute with Penman by submitting handwritten complaints to the Presbytery. ${ }^{42}$ In so doing, he was able to channel frustration with Penman's method of dealing with Crichton's godly parishioners, increase its visibility in the ecclesiastical politics of the region and collate information provided to him by various, as yet unnamed, informants. In late 1656, Bartrum entered three new supplications containing 'gross scandals' against the minister and submitted them en masse to the Synod's first meeting. Penman's requests for copies of the accusations to study were granted but he could not keep up with the pace with which Bartrum entered his libels. ${ }^{43}$ Early in 1657, Bartrum had obtained information that sensationally accused Penman of falsifying a bond for a loan by including the name of his brother, Robert, in the bill. A separate libel submitted by Bartrum suggested that Robert Penman had proclaimed that 'tho his brother wes a minister he wes a false knave'. ${ }^{44}$ The details of the other allegations made against Gideon Penman do not survive. Reflecting the scope of Bartrum's information, the Synod clerk recorded how the ministers 'found some particulars frivolous, others grosse and scandalous and others scandalous but no probabilitie can be seene how to get them proven'. ${ }^{45}$ Bartrum had multiple sources of information that went far beyond his roles of schoolmaster and session clerk. Members of the committee investigated 'upon such particulars as ar relevant and where there is probabilitie to prove' any wrongdoing. ${ }^{46}$ While members of the Committee referred the claims of forgery to a civil court, they collected the depositions of over a dozen witnesses to throw further light on other details of Penman's case.

Bartrum's witnesses were drawn from a group of self-consciously godly parishioners in and around Crichton. Bartrum appointed Susanna Nisbit, Margaret Scott and their husbands to prove various accusations in his libel in April 1657. Penman told the committee of the Synod that they were not credible witnesses because they bore him malice, had attempted to change the minds of other witnesses and had told other parishioners to stand by

\footnotetext{
${ }^{41} \mathrm{NRS}, \mathrm{CH} 2 / 424 / 4$, ff. 273-4.

${ }^{42}$ We know remarkably little about the culture of local petitioning in early modern Scotland. Petitions in the north of England, however, served to escalate the severity of a legal actions. See Steve Hindle, 'The keeping of the public peace', in Paul Griffiths, Adam Fox \& Steve Hindle, The Experience of Authority in Early Modern England (Basingstoke, 1996), 213-248.

${ }^{43}$ The Minutes of the Synod of Lothian and Tweeddale, 1648-1659, ed. Chris R. Langley (London: Scottish History Society 2016), 217-18.

${ }^{44}$ Lothian and Tweeddale, 219, 222, 224-5.

${ }^{45}$ Lothian and Tweeddale, 219.

${ }^{46}$ Lothian and Tweeddale, 280.
} 
their accusations against the minister because 'God hath a work in it'. In responses that echo the work of the Protester Samuel Rutherford and godly writers elsewhere, Nisbit admitted to calling Penman a 'soule murtherer', that he had 'the blood of soules upon his head' and that 'if he did not repent, he would repent the time he preached'. ${ }^{47}$ Other parishioners were reported to have said 'they could indure him wel to be a neighbour unto them but not to be there [sic] minister'. ${ }^{48}$ For his part, Penman accused Susanna Nisbit of working directly with James Bartrum to steal the session book out of the minister's chamber on the schoolmaster's behalf. ${ }^{49}$ Penman verbally attacked Nisbit, calling her 'ane ignorant queene, a considerat woman, and full of the spirit'. ${ }^{50}$ The minister of Crichton was at war with the godly in his congregation.

Over a year after Bartrum entered his original complaint and after a lengthy investigation, the Synod pronounced a sentence of suspension on Penman in January $1658 .{ }^{51}$ His offence was that he has failed to keep control of his congregation: he had not managed to prove his libels against Bartrum and Nisbit and the committee found that the kirk session register was not as orderly as they might have expected (probably unsurprising considering he was having a feud with the clerk, Bartrum). The members of the Committee anticipated that Penman's suspension would be a short-term measure, allowing the pressure to ease in his parish, as they instructed him to return to the next Synod meeting in May so his preaching could be assessed. ${ }^{52}$ Unfortunately for Penman, as we shall see, the godly in Crichton were not content with their minister merely being suspended.

The battle between Gideon Penman and his parishioners in Crichton demonstrated the full arsenal of weapons available to godly laymen and ministers alike. Attacks on ministers were not solely religious in nature but often blurred the lines between his ecclesiastical function and secular disagreements. Arguments like this were characterised not by one accusation but by a litany of them. Indeed, Penman's eventual suspension stemmed from a number of separate legal actions and a multitude of written petitions and libels that all served to discredit him. While these cases were investigated separately, they were highly coordinated as

\footnotetext{
${ }^{47}$ Lothian and Tweeddale, 240; Samuel Rutherford, The Divine Right of Church Government (London, 1646), 28; Tom Webster, Godly Clergy in Early Stuart England: The Caroline Puritan Movement c. 1620-1643 (Cambridge, 1997), 96-7.

${ }^{48}$ Lothian and Tweeddale, 240-1.

${ }^{49}$ Lothian and Tweeddale, 308.

${ }^{50}$ Lothian and Tweeddale, 240-1.

${ }^{51}$ Lothian and Tweeddale, 308-9.

${ }^{52}$ Lothian and Tweeddale, 308-9, 325.
} 
participants in these feuds used additional legal actions to bring further pressure on their target and carefully timed the release of their articles for maximum effect. Fighting a legal battle on more than one front was costly and it increased the possibility of making a mistake in one's defence. Penman's enemies created a legal noose, thread by thread, for their minister.

Godly Agitation

Prominent Protesters elsewhere in Midlothian and Tweeddale took a great interest in Penman's case. John Sinclair, the Protesting preacher at nearby Ormiston, was particularly vocal in campaigning against the minister of Crichton. Sinclair openly supported the Protesting movement but continued to sit at meetings of the Presbytery of Dalkeith and the Synod of Lothian and Tweeddale. ${ }^{53}$ Several years earlier, Sinclair told one prominent separatist that while he disagreed with some of the Kirk of Scotland's policies he would not condone separation in word or deed from 'the national church' and would, instead, work to reform it from within. ${ }^{54}$ Sinclair's articulation of moderate Protester thought matched the aims of the godly in Crichton: seeking to reform the Kirk internally, rather than seceding from it altogether. ${ }^{55}$

In April 1657, the irregularities of Gideon Penman's case attracted Sinclair's attention. The minister of Ormiston demanded that Penman should be immediately suspended pending investigation rather than continuing in office and he was actively involved in encouraging those who paid Penman's stipend to withhold their teinds to pressure him into submission. ${ }^{56}$ Shortly after Penman's actual suspension in January 1658, Sinclair reported to the Presbytery that Penman had urged one of his parishioners, John Hair, to give in a libel against him and later complained that the entire allegation was forged by Penman in an attempt to discredit his ministry in Ormiston. In front of his session at Ormiston, Sinclair blasted Penman by calling him 'the skybald of Creichtoun'. ${ }^{57}$ Sinclair's denunciations of

\footnotetext{
${ }^{53}$ Scott, Fasti, i, 339.

${ }^{54}$ Diary of Alexander Jaffray, ed. John Barclay (London, 1833), 98.

55 Pace Holfelder, 'Factionalism in the Kirk', 302.

${ }^{56} \mathrm{NRS}, \mathrm{CH} 2 / 424 / 4$, f. 276.

57 Lothian and Tweeddale, p.376. 'Skybald' denotes a scamp, rascal, rogue, a worthless person who is contemptible.
} 
Penman's ministry reflect a more aggressive form of clerical masculinity than urged in conduct books. ${ }^{58}$

In addition to targeting Penman, Sinclair and his Protester colleagues in the Presbytery of Dalkeith actively pursued anyone who they considered to be associated with him. Existing interpersonal disputes played a key part in these attacks. In September 1658, the session at Crichton, now dominated again by Alexander Borthwick of Sauchnell, reported to the Presbytery that one of the parish's senior elders, Martin Grindlay, was being investigated for attempting to change the date on an agreement with a parishioner in Crichton. Sinclair, being present at the Presbytery meeting, exclaimed that 'Mr Gideon Penman was a winker at [Grindlay's] knaverie' and, later, that Grindlay was 'employed' by Penman to change the contract. ${ }^{59}$ At his first appearance to explain his actions, Grindlay revealed to the Presbytery that Sinclair was the person who had presented the case to the session of Crichton in the first place.

Sinclair and his circle of Protesters were intimately connected to Crichton's network of godly laity through private meetings, correspondence and mutual interest in reforming the Kirk from within. John Sinclair sat on the committees that judged Bartrum's allegations against Penman alongside Andrew Hay of Craignethan, the factor of Elizabeth Wariston, by this time Lady Humbie, one of the most prominent landowners in the parish. ${ }^{60}$ Hay of Craignethan's diary reveals how the two men became quite close in mid-1659 culminating in Hay attending one of Sinclair's fast-day sermons at Ormiston in August of that year. Hay relied on Sinclair's access to Presbytery records to improve Humbie's chances of ousting Penman while Hay cultivated a personal relationship with Sinclair through the former's desire to learn Hebrew. For his part, Hay managed Lady Humbie's interests, including land assigned to another prominent elder in Crichton, Andrew Borthwick of Sauchnell. Borthwick was clearly trusted by Humbie as he borrowed a substantial amount of money from her in March $1659 .{ }^{61}$ Scholars have previously identified how godly sociability of this type could offer spiritual kinship, consolation and genuine friendship to its members. ${ }^{62}$ This particular

\footnotetext{
${ }^{58}$ Janay Nugent, 'Reformed masculinity: Ministers, fathers and male heads of households, 1560-1660', in Lynn Abrams \& Elizabeth L. Ewan (eds), Nine Centuries of Man: Manhood and Masculinity in Scottish History (Oxford, 2017), 39-52.

${ }^{59} \mathrm{NRS}, \mathrm{CH} 2 / 424 / 4$, f. 356.

${ }^{60} \mathrm{NRS}, \mathrm{CC} 8 / 8 / 670$, ff. $148-9$.

${ }^{61} \mathrm{NRS}, \mathrm{RD} 2 / 3$, ff. 429-30.

${ }^{62}$ Mullan, Scottish Puritanism, ch. 1; Jamie Reid-Baxter, 'Elizabeth Melville, Lady Culross: New light from Fife', Innes Review, 68 (2017), 38-77; Diane Willen, 'A godly friendship: Thomas Gataker and William Bradshaw', The Seventeenth Century (2019), 1-23.
} 
godly network reminds us that such groups were also bound together by ties of economic cooperation. They used these relationships to agitate for change within the Kirk.

The period immediately after Penman's suspension reflects the Protesters' increasing interest in the ministry of Crichton and the ways they used existing channels to articulate their grievances. In February 1659, Penman entered a petition to the Synod asking to be restored to his ministry. Prior to the meeting, Alexander Borthwick of Sauchnell entered a civil suit to the English Commissioners for the Administration of Justice in Scotland against Grindlay for conspiring with Penman to gain access to the rents of lands formerly belonging to the Church. In a separate petition, Elizabeth Johnston, now Lady Humbie, pointed to the newly-opened civil suit in order to delay Penman's return to the ministry. Humbie and Borthwick had collaborated before the meeting and, presented with this new information, the Synod was forced to delay its discussion of the matter until its next meeting in May. Like many women of her rank, Humbie, aided by collaborators, was very active in legal affairs and would use this knowledge to defend the Protesters' interests in the region. ${ }^{63}$

The wider network of Protesters used their positions on Church judiciaries to affect change from within and to thwart Penman's efforts to be reponed to the ministry. Hay sat on the Synod committee as ruling elder for the Presbytery of Biggar but nevertheless used his influence to obtain information on Penman, share it with colleagues and build a case against him. In the afternoon of 6 May 1659, the Synod proceeded to discuss Penman's case with Hay present. Understanding Andrew Hay's proximity to one of his patrons, Penman submitted a verbal request demanding that Hay should not be permitted to vote and should be removed from the sitting. Members of the assembly discussed Hay's suitability for over an hour but Hay 'satt still' in a calculated act of defiance. At nine o'clock, unable to break the impasse, the Synod deferred judgement until a later meeting. Hay, recognising the success of his filibuster recorded in his diary that ' $w e$ were glad to let all things ly'. ${ }^{64}$ Protesters like Hay and Sinclair had huge knowledge of the procedures of ecclesiastical assemblies. They exploited their membership of such bodies to provide them with otherwise private information and to delay the readmission of their opponents to positions within the ministry.

The action climaxed at the Synod committee meeting of 8 May where the Protesting coalition deployed their knowledge of ecclesiastical law and the accepted methods of

\footnotetext{
${ }^{63}$ Nicola Cowmeadow, “'In sum what have I don for God or my soule this day?": The religious writing of Katherine, first Duchess of Atholl (1662-1707)', Journal of Scottish Historical Studies, 34 (2014), 14-15; Elizabeth Ewan \& Maureen M. Meikle, 'Introduction: A monstrous regiment of women?', in Elizabeth Ewan \& Maureen M. Meikle (eds), Women in Scotland c.1100-c.1750 (East Linton, 1999), xxvii.

${ }^{64}$ The Diary of Andrew Hay of Craignethan 1659-1660, ed. Alexander George Reid, Scottish History Society (Edinburgh, 1901), 7. My emphasis.
} 
supplication to launch a coordinated strike on the credibility of Penman's ministry. Aware that Penman would reiterate his desire to be reponed to his ministry, Lady Humbie's chamberlain, Thomas Pait, presented a letter subscribed by Elizabeth Johnston of Wariston, wife of Archibald Johnston of Wariston, as well as other Protesting landowners from across Midlothian, requesting that Gideon Penman should be deposed from his ministry because he had 'intrometted with the stipend...the tyme of his suspensione'. ${ }^{65}$ Borthwick appeared alongside Pait and delivered another supplication claiming that Penman had been cited before the Commissioners for the Administration of Justice of the Peace in Scotland, and would, before long, be found guilty of meddling with the parish stipend during his suspension. John Sinclair stood up and presented a third petition against Penman and James Bartrum, former schoolmaster, completed the drama by submitting a fourth petition to the Synod which complained about Penman's conduct (and may have alluded to a separate suit brought by Penman against him before the Justices of the Peace). ${ }^{66}$ Penman was dumfounded, he cited extenuating circumstances for receiving rents from parish lands during his suspension but was nevertheless continued in his suspension until later in the year. The four petitions presented to the Synod of Lothian and Tweeddale represent a coordinated pan-Midlothian Protester attack on a single minister by using accepted modes of dissent within the structures of the Kirk of Scotland.

Surviving extracts from the diary of Andrew Hay of Craignethan reveal the amount of organisation that occurred away from the church meeting but that would have such a dramatic impact on its proceedings. The need for such discussions was accelerated by the rapid disintegration of English judicial courts - including the Commissioners for the Administration of Justice - following the fall of the Protectorate in May 1659. The Protesters were forced to pursue Penman in a new case before the Court of Session. ${ }^{67}$ On 20 July, Andrew Borthwick conferred with Andrew Hay and, later, Sir John Cheislie, regarding the 'great presumptions of [Penman] appropriating the church rent to his oune use' ${ }^{68}$ Hay found property contracts drawn up earlier in the century that corroborated Borthwick's claim. The Protesters agreed on a legal strategy that would allow them to immediately respond if the assembly rejected their first attempt to bring down Penman. Throughout proceedings, Andrew Hay was in close correspondence with John Sinclair, asking the minister of Ormiston

\footnotetext{
${ }^{65}$ Lothian and Tweeddale, 421-2.

${ }^{66}$ Lothian and Tweeddale, 421-2.

${ }^{67}$ Hay of Craignethan, 20; Maurice Lee Jr., The Heiresses of Buccleuch: Marriage, Money and Politics in Seventeenth-Century Britain (East Linton, 1996), 40.

${ }^{68}$ Hay of Craignethan, 85.
} 
for legal precedents, acts of the General Assembly and other advice. Such planning usually remains hidden from the record but, taken together, the petitions by both Borthwick, Bartrum and Hay represent a unified strategy to attack Penman's legal and moral standing.

The Protesters implemented their strategy at the next meeting of the Synod in August. Borthwick entered his written petition complaining that Penman had converted lands that belonged to the Kirk and pretended that they were his own possessions. Next, Borthwick asserted that Penman must have changed his copies of the contracts relating to the lands because they did not match those in his possession. Following their pre-planned strategy at the same meeting, James Bartrum appeared before the Synod and entered a separate complaint about Penman's personal conduct including a reference to an 'obscene' expression uttered at the table of Andrew Borthwick (information that Borthwick had shared with Bartrum). ${ }^{69}$ A letter from John Sinclair arrived at the Committee meeting reporting in similar concerns. ${ }^{70}$ The rather matter-of-fact registers left behind by the Synod conceal the amount of behind-the-scenes strategising that accompanied most petitions that were delivered for discussion. The fact that the Synod had to postpone debating Penman's return to the ministry until the following month indicates the Protesters' success.

The machinations behind the Humbie/Borthwick/Sinclair coalition are largely hidden from the official ecclesiastical records. Upon first inspection, their actions against Gideon Penman appear to be separate concerns. Occasionally, one legal action against Penman strengthened another but presbytery and synod records present them as separate endeavours. These records rarely commented on the machinations that occurred away from the presbytery or synod meeting, the private attempts to cajole and persuade others to support a petition. The tone of official church documents, the very nature of how they were recorded, tends to reduce the visibility of division and intrigue within a Church assembly and the amount of organisation that occurred away from it.

The survival of Andrew Hay's diary reveals that the separate petitions against Penman were not at all coincidental. Rather, they were part of a highly organised campaign waged by a godly literati attempting to engineer the ministry in the Central Belt. The godly interest worked to subvert the ministry of clerics like Penman by using existing tools and exploiting their own intimate knowledge of and access to wholly traditional levers of power: church courts, patronage and client networks. Critically, these men and women worked

\footnotetext{
${ }^{69} \mathrm{NRS}, \mathrm{CH} 2 / 252 / 4$, ff. $13-14$.

${ }^{70} \mathrm{NRS}, \mathrm{CH} 2 / 252 / 4$, f. 13.
} 
within the Church rather than choosing to secede from it altogether. The Protesters' constant use of manuscript petitions 'performed functions that could not easily be performed' by printed books or pamphlets: they could engage directly with the local ecclesiastical hierarchy to effect change rather than engage with a polemical audience. ${ }^{71}$ Their strenuous and costly attempts to agitate for change reflect a commitment to reforming, rather than leaving, the national Church.

The Moderate Response

The pan-Lothian godly agitation that opposed Gideon Penman did not occur in a vacuum. Rather, it operated in a climate where the ecclesiastical and civil levers of power were controlled by moderates at both a local and national level. The Protesters' agitation against Penman stemmed from their belief that the minister of Crichton was unfit to serve the office. The ferocity of their activity, however, was because Penman and a largely unseen network of backers were so effective at repelling their attacks. While we lack the personal correspondence of the ringleaders of the moderate reaction, we can piece together the ways in which a coalition of Resolutioners backed and defended Gideon Penman's ministry from the power of godly opposition. Moreover, extreme Protesters and Resolutioners were anxious to prevent the occupying English government intervening in ecclesiastical affairs in the event of an impasse. ${ }^{72}$ As a consequence, moderate ministers from across the region made it increasingly difficult for the godly coalition to prevail. After the Restoration, despite an attempt at conciliation by the moderates in the provincial assembly, the notoriety of the Midlothian godly faction and the conformity of Penman and his backers led to the vilification of the Protesters' actions.

While the godly faction of Lady Humbie, Andrew Borthwick and John Sinclair lobbied against Gideon Penman, one of the other heritors of Crichton warned Andrew Hay of Craignethan that their agitation 'wold do no good'. ${ }^{73}$ This comment was motivated less out of support for Gideon Penman than out of a fear that, should the godly fail to carry the day, the occupying English government would intervene into the ecclesiastical affairs of the parish. Indeed, Lady Humbie's mother received a letter from General Monck in May 1659 requesting that she persuade her daughter and her associates 'not to trouble Mr Gedeon

\footnotetext{
${ }^{71}$ Sebastiaan Verweij, The Literary Culture of Early Modern Scotland (Oxford, 2016), 245-6.

72 Frances Dow, Cromwellian Scotland, 1651-60 (Edinburgh, 1979).

${ }^{73}$ Hay of Craignethan, 153.
} 
Penman' any longer. ${ }^{74}$ Monck had based himself in the house of one of the most prominent heritors of Crichton - the Countess of Buccleuch in nearby Dalkeith - and was aware of the machinations in the parish because of Buccleuch's involvement in local affairs. The occupational government had already established a precedent for intervening in parochial Kirk business in the event of serious disagreement. In addition to 'rubber stamping' nominations for vacant parishes, the English authorities actively intervened in appointments in the south west earlier in the decade and engineered the ministry of nearby Bathgate in $1654 .{ }^{75}$ The Midlothian godly faction needed to tread carefully to achieve its aims without provoking sufficient opposition that the English authorities would deign to intervene.

While English authorities were pressuring the Protesters to withdraw from their confrontation with Penman, moderate backers were helping reduce the financial impact of suspension on the minister. Following an Act of General Assembly in 1648, suspended ministers were prohibited from drawing money from their stipend during the time of their suspension. ${ }^{76}$ While this money could be claimed retrospectively if the minister returned to his ministry, he could not claim any of it in anticipation that he would be cleared of his suspension. Suspended ministers were unsurprisingly eager to have their cases resolved in order to obtain some form of income. Penman's situation was exacerbated by the escalating legal costs arising from civil and ecclesiastical litigation brought by the Protesters. There is some evidence to suggest that Penman received support from at least one of the parish heritors - Wauchop of Cakemuir - by receiving money from his lands as a gift from the patron. ${ }^{77}$ We can be certain that Penman was using his family ties to obtain a degree of economic security while suspended. Fragments of papers from the Court of Session reveal that between 1658 and 1659, Penman received five hundred merks Scots from George Stirling, servant to Gideon's eldest brother Adam Penman, minister of Cockpen. Both brothers signed the agreement at Cockpen on the 6 April 1658 alongside John Knox, the short-lived moderate minister of nearby Carrington. ${ }^{78}$ The timing of the loan (just three months after Gideon Penman's suspension from the ministry at Crichton and at the height of legal action against him) and its value (around two thirds the value of his annual stipend at

\footnotetext{
${ }^{74}$ Hay of Craignethan, 6.

75 Kirsteen M. MacKenzie, The Solemn League and Covenant of the Three Kingdoms and the Cromwellian Union, 1643-1663 (London, 2018), 134-5; Holfelder, 'Factionalism in the Kirk', 204-5; Laurence A. B. Whitley, A Great Grievance: Ecclesiastical Lay Patronage in Scotland until 1750 (Oregon, 2013), 62-5.

${ }^{76}$ Records of the Kirk of Scotland Containing the Acts and Proceedings of the General Assemblies, ed. Alexander Peterkin (Edinburgh, 1843), 510.

${ }^{77} \mathrm{NRS}, \mathrm{CH} 2 / 252 / 4$, ff. 57-8.

${ }^{78} \mathrm{NRS}, \mathrm{RD} 4 / 3$, ff. 102-3.
} 
Crichton), indicates both the power of godly agitation in bringing Penman so close to financial and professional ruin as well as the networks of support on which a minister could rely in a time of dire need. ${ }^{79}$

Penman's backers in Crichton acted to discredit Protester opponents whenever possible. Martin Grindlay, a senior elder in Crichton who was accused by John Sinclair of being an associate of Gideon Penman, registered numerous complaints about the conduct of another elder, Andrew Borthwick in 1657, ranging from allegations that Borthwick was a drunkard, that he overlooked disciplinary infractions of his tenants and transacted business on the sabbath. ${ }^{80}$ It appears that Penman's backers had control of the kirk session by the Autumn of 1659 and used their position to attack the minister's opponents. For example, in December 1659, the session at Crichton passed on a reference to the Presbytery asking for help dealing with a case involving Andrew Borthwick who had reportedly been heard swearing at Dalkeith fair. ${ }^{81}$ The interpersonal disputes between Borthwick and Grindlay reflect the ways in which ecclesiastical politics could become quickly defined by the personal animosities of its protagonists. As the ecclesiastical controversies of the 1650s had considerable lay involvement, they mirrored the language of noble dispute that had developed over the previous century. ${ }^{82}$

Moderates in the Synod and a great many witnesses who were cited to the final committee meeting in October and November 1659 were largely unmoved by the Protesters' petitions and had grown weary of the lengthy process. The Committee accepted Penman's explanation that he had inherited rights to the disputed lands from his father, who had access to them since $1610 .{ }^{83}$ They rejected Bartrum's accusation that Penman had said something offensive at Andrew Borthwick's table and refused to accept Borthwick as a key witness because of his proximity to the case. One of the key witnesses to the land dispute wrote to the Synod complaining that 'he had alreadie declaired quhat he knew in Mr Gideon Penmans bussines at severall tymes' before civil and ecclesiastical courts and saw no need to do so again. ${ }^{84}$ He was not alone. Despite protests from Borthwick and Sinclair, the Synod rejected the main grounds of the dispute with Penman.

\footnotetext{
${ }^{79}$ All three men would conform to episcopacy in 1663. See James Hunter, Fala and Soutra: Including a History of the Famous 'Domus de Soltre' (Edinburgh, 1892), 86.

${ }^{80} \mathrm{NRS}, \mathrm{CH} 2 / 424 / 4$, ff. 366-7, 73-5.

${ }^{81} \mathrm{NRS}, \mathrm{CH} 2 / 424 / 4$, f. 402.

${ }^{82}$ Keith Brown, Noble Power in Scotland from the Reformation to the Revolution (Edinburgh, 2011).

${ }^{83} \mathrm{NRS}, \mathrm{CH} 2 / 252 / 4$, ff. 15-16.

${ }^{84} \mathrm{NRS}, \mathrm{CH} 2 / 252 / 4$, f. 17.
} 
Moderates in the Synod attempted to break the impasse in Penman's case without acquiescing to the demands of the Protesters to remove Penman altogether. Between August and November 1659, moderate ministers were appointed by the Synod to discuss the possibility of Penman accepting an assistant minister to help him fulfil his pastoral responsibilities in Crichton while also serving to soften Protesters' complaints against him. The appointment of an assistant to serve alongside a problematic minister was a common tactic to alleviate parish disputes. ${ }^{85}$ The first round of talks proved unsuccessful and the Synod appointed a separate delegation to discuss the same matter with Penman in November where the Synod made it a condition of Penman's reinstatement to the ministry that he accept a helper. Penman eventually offered five hundred merks of his annual income to the new minister but demanded that the Synod lift his suspension before the choosing of the newcomer - 'so that he may have a voice in the electione' - and that he keep the manse for the use of his own family. Penman submitted his offer in writing. ${ }^{86}$

The Protesters had little choice but comply with the order to elect a helper to Penman or risk losing their influence in the parish. While Sinclair protested that neither the Synod nor the Presbytery should have any say in the election and that it should be settled by the local landowners, Borthwick and Lady Humbie engaged with the process nonetheless. ${ }^{87}$ The Synod established a list of three recently-trained ministers to preach in Crichton over the course of three Sundays in December: John Philp, Robert Elliott and Alexander Heriot. The Synod instructed the parishioners that 'if two of the young men upon the list shall only go and preach, and that the third shall refuise or neglect', the parish would elect one of the two. At the start of January, the elders reported that only two of the men had arrived. ${ }^{88}$ Following the Synod's initial instructions, the session should have moved to elect one of these men but the absent minister, Alexander Heriot, was Lady Humbie's preferred candidate. Humbie requested that the election should be delayed until Heriot - or 'failyeing of him till some other' of her choosing - be given the chance to preach before the congregation. ${ }^{89}$ The Synod, eager to prevent the Protesters from suggesting that its members had impinged on the outcome, accepted and sent a delegation to implore Heriot to preach. Aghast, moderates in the parish demanded that the 'election might go on' as 'the Committee of the Synod had

\footnotetext{
${ }^{85}$ Chris R. Langley, Worship, Civil War and Community, 1638-1660 (Routledge, 2016), 25-6.

${ }^{86}$ NRS, CH2/252/4, ff. 245-6.

${ }^{87} \mathrm{NRS}, \mathrm{CH} 2 / 424 / 4$, ff. 401-2.

${ }^{88} \mathrm{NRS}, \mathrm{CH} 2 / 252 / 4$, f.48.

${ }^{89} \mathrm{NRS}, \mathrm{CH} 2 / 252 / 4$, f. 50 .
} 
declaired.${ }^{90}$ Unable to act for fear of exacerbating the dispute, the Synod simply asked the elders on the session at Crichton what they thought best. The election was delayed. The machinations of electing a helper reflect the continuing influence of local landowners over ecclesiastical appointments despite the abolition of lay patronage in $1649 .{ }^{91}$

The Protesters continued to petition the Synod to ensure that a suitably godly assistant was found. Lady Humbie sent Thomas Pait as her representative to Edinburgh on 10 January 1660 with a supplication that was subscribed by a godly remnant of the congregation at Crichton. The petition asked the committee to send delegates to Thomas Heriot to persuade him to attend his trials. As a contingency plan, the petition asked that 'the Committee would appoint Mr Richard Howiesoun to preach at the said kirk'. After hearing all four, the petitioners requested, the session 'might be the more rype to choyse one of them' ${ }^{92}$ Desperate to proceed, the Moderator of the Synod told his colleagues that he had already spoken to Heriot and that the young man 'absolutely refused' to be part of the trial. Andrew Borthwick and Thomas Pait appeared dejected before the Committee informing the ministers 'they had been dealing with [Heriot] but he refused, and that they would not desire him who wes not willing' ${ }^{93}$ The representatives shifted their attention to getting Richard Howieson to preach. Andrew Borthwick persuaded an initially unwilling Howieson to stand as his faction's preferred candidate.

Penman's demand that he be reponed before the election of his helper became a point of contention between moderates and the Protesters. Removing Penman's suspension prior to the election would have given the minister a voice in selecting his assistant and, predictably, Protesters were eager to avoid this outcome. Borthwick demanded that 'Committee would provyde the kirk of Creichtoun with a fellow labourer to Mr Gideon Penman before the sentence of suspension should be taken off, and that the said Mr Gideon might have no hand in the electione'. ${ }^{94}$ The situation became more urgent when the Synod appointed Penman to make his repentance before the congregation at Crichton at the end of January $1660 .{ }^{95}$ Acting quickly, representatives appeared before the Synod on 7 February and delivered a paper asking the Synod to further define some of the parameters of the election before they committed to agreeing the arrangements of the stipend. Their demands merit rehearsing in full:

\footnotetext{
${ }^{90} \mathrm{NRS}, \mathrm{CH} 2 / 252 / 4$, f. 50.

${ }^{91}$ Whitley, A Great Grievance, 51-62.

92 NRS, CH2/252/4, f. 51.

${ }^{93} \mathrm{NRS}, \mathrm{CH} 2 / 252 / 4$, f. 51.

${ }^{94} \mathrm{NRS}, \mathrm{CH} 2 / 252 / 4$, f. 48.

$95 \mathrm{NRS}, \mathrm{CH} 2 / 252 / 4$, ff. 50-1.
} 
first that the said Mr Gideon his mouth be not opened till the enterant so elected, have accepted and passed his tryells in order to that call ther. Secondly that if it be found and declaired, if the enterant (at the pleasure of God) shall be removed be death or be ane call to ane uther congregation that then and in that cais his place may be vacant as now, and that they may have the same priviliedge to call and elect ane uther upon the samen ground. And thridly [sic] that the Committee would be cairfull as to the provyding of the entreant sufficiently with the better pairt of the stipend and uther kirk benefeits for his encouragments. And lastly that the Committee would appoynt these of their number who are to come out for the electione to take cognitione of the manse and gleib for better accomodatione and to reporte. ${ }^{96}$

The timing of their demands was critical. The petition sought to delay Penman's readmission to his ministry until after the election. Moreover, it also attempted to set a precedent where the parish would have the right to nominate and install another assistant if their preferred candidate were to die or move to a more lucrative charge elsewhere. Finally, if these conditions were met, the petitioners invited the Committee to discuss the stipend further. The supplication did not reject the validity of Penman's vote - should he be suitably readmitted but they sought to arrange the vote in a way that was beneficial to their aims.

The Protesters were not alone in trying to safeguard their interests in the election of Penman's assistant. A separate faction of moderates - led by John Lightfoot an elder on the parish session and signed by Major Archibald Waddell and 'uther heretors and elders of that paroche' - asked the Synod to send more young ministers for consideration as assistant minister and requested that the Committee 'would open Mr Gideon Penman's mouth that they may no longer be frustrate of the benefite of his ministrie' ${ }^{97}$ Protected by Penman's backers, the meeting moved to discuss the removal of his suspension. Unfortunately, the minutes of the Committee do not give an insight into the full details of the ministers' deliberations but without Hay and Sinclair in its ranks the committee recorded no contrary voices. Gideon Penman apologised for some of the more unsavoury aspects of his conduct

\footnotetext{
${ }^{96} \mathrm{NRS}, \mathrm{CH} 2 / 252 / 4$, ff. 52-3.

${ }^{97} \mathrm{NRS}, \mathrm{CH} 2 / 252 / 4$, f. 54.
} 
and was reinstated to the ministry before lunchtime. ${ }^{98}$ Buoyed with confidence, his readmission was to be proclaimed from the pulpit the following Sunday: the same day that the election of his assistant would take place.

On 14 February 1660, members of the kirk session convened in the parish church and were joined by a full representation from the leading landowners of the region: Patrick Scott on behalf of the young Countess of Buccleuch, William Cheislie represented the interests of Lady Humbie and Martin Grindlay was present on behalf of the Earl of Lauderdale who was absent in the Low Countries with the exiled Charles II. The meeting opened with a sermon by Oliver Colt, minister at Musselburgh, on Jeremiah 5: 14 and a prayer by his East Lothian colleague Thomas Kirkcaldy, minister at Tranent. ${ }^{99}$ Presiding over the meeting, Kirkcaldy informed those present of the day's business: the election of Robert Elliott, Richard Howieson or John Philp as assistant to Gideon Penman. Kirkcaldy required that the most prominent of the parish landowners should withdraw themselves 'for a tyme that the session might be the mair frie in their election' as most of the elders were 'removea[bi]ll tennents' of the heritors. William Cheislie, on behalf of the Lady Humbie, refused to leave the room, while Patrick Scott, representing the Countess of Buccleuch, also sat still. Before moving to the election, Cheislie protested that the minister, Gideon Penman, should not be permitted to vote. One of the parish elders, Andrew Borthwick of Sauchnell, protested in a similar manner and Patrick Scott entered his exceptions to the election 'in the samen termes'. Expecting the protests, Gideon Penman told Kirkcaldy that Andrew Borthwick should be excluded from the vote as 'he wes under some scandalls' before the parish kirk session. Kirkcaldy dismissed the protests and continued to the election. ${ }^{100}$

Kirkcaldy, in his role as moderator, reminded the elders of the oath of fidelity they had taken when they were elected to the kirk session. ${ }^{101}$ One by one, the elders voiced their opinion on the election. Cheislie, refusing to move, was an eyewitness to the events that followed and later described the scene. Martin Grindlay, Lauderdale's factor, also stayed in the room and 'did move on[e] of the elders' as he was voting for Richard Howiesone to change his vote and choose Robert Elliott, instead. Cheislie reported that, after the election, one of the elders mentioned that he could not remember much of Robert Elliott's sermon three weeks before but voted for him instead of either of the other two ministers 'as the best

\footnotetext{
${ }^{98} \mathrm{NRS}, \mathrm{CH} 2 / 252 / 4$, f. 54.

${ }^{99}$ Hew Scott, Fasti Ecclesiae Scoticanae, i (Edinburgh, 1915), 325, 396.

${ }^{100}$ National Records of Scotland (hereafter NRS), CH2/252/4, ff. 54-7.

${ }^{101}$ For more on the oath of office, see: Chris R. Langley, "In the execution of his office: Lay officials and the exercise of ecclesiastical discipline in Scotland, c. 1600-1660', The Seventeenth Century, 33 (2018). 4-7; Todd, Culture of Protestantism, 369-85.
} 
man be reporte' ${ }^{102}$ Nevertheless, after taking the votes of all ten elders, the session was split: five votes for Robert Elliott and five for Richard Howieson. Thomas Kirkcaldy then turned to the only clerical member of the session, Gideon Penman, to ask how he would vote. His choice was unequivocal: Robert Elliott. Drawing the election to a close, the moderator announced that Robert Elliott 'wes the man who they desired'. As the other landowners returned to hear the result, William Cheislie repeated his previous protest and, in chorus with Andrew Borthwick of Sauchnell, added that 'the Lady Humbie should not be lyed to give any mentinance to the said Mr Robert'. Immediately, four of the other heritors' representatives protested that they should not be expected to pay for the shortfall in the stipend created by Lady Humbie's actions. ${ }^{103}$ With the meeting in chaos but with no further orders to act, Kirkcaldy had no choice but dissolve the gathering.

Aware of the threat posed by local Protesters, the election was a masterclass of stage management by moderates. First, Thomas Kirkcaldy's opening sermon on Jeremiah 5: 14 criticised those who misunderstand God's commands in a thinly veiled attack on the Protesters. ${ }^{104}$ Second, Kirkcaldy had allowed his colleague, Oliver Colt, to have a voice in the election of Penman's assistant. While this may have been an oversight on Kirkcaldy's part, Colt, the minister of Musselburgh, was well known for his moderate views and would conform to episcopacy after the Restoration. ${ }^{105}$ After the elders had voted, five elders had chosen Robert Elliott and five had selected Richard Howieson, the Protesters' preferred candidate. Penman, his readmission to the ministry announced that very day, held the casting vote. He rejected Howieson and voted for Elliott. Kirkcaldy, the moderator, did not question the validity of Penman's vote.

While it was clear that moderates in the Synod had stacked the deck in their own favour, the Protesters debated the result of the election without rejecting the legality of the authority that oversaw it. In the following weeks, on behalf of Lady Humbie, William Cheislie challenged how those overseeing the election had interpreted the Synod's commission in allowing Gideon Penman to vote at all. Cheislie complained that 'the Synod haveing appoynted that ther shall be another minister at Creichtoun, it seems above all question that they never intended that Mr Gideon should have the sole electione or casting voice (which upon the mater are one) of the uther ministers to serve at that church'. ${ }^{106}$ The

\footnotetext{
102 NRS, CH2/252/4, f. 56. My emphasis.

${ }^{103} \mathrm{NRS}, \mathrm{CH} 2 / 252 / 4$, f. 55.

${ }^{104}$ NRS, CH2/252/4, ff. 54-5.

105 Scott, Fasti, i, 325.

${ }^{106}$ NRS, CH2/252/4, ff. 56-7.
} 
men overseeing the election had, Cheislie argued, deliberately misrepresented their instructions and allowed Penman to have the casting vote. Cheislie then came perilously close to rejecting the authority of the Synod altogether. He claimed that, following Gideon's lengthy suspension, 'it is very hard that his first act efter he is reponed should be one of such importance as this'. ${ }^{107}$ Cheislie was aware that, once restored to his post, the Synod could not have prohibited Penman from having a voice in the election. With the final of these complaints, Cheislie reminded the Synod that failure to consider these complaints would result in Lady Humbie withdrawing her funding for the assistant minister. Cheislie's bitter complaints reflect the tightrope walked by Protesters when openly discussing their grievances with established Church judiciaries. It is little wonder that they resorted to other legal remedies.

The Synod's attempts to block Protester influence in the region hinged on its ability to convince other moderate parishioners to contribute more money or to persuade Humbie to finance a minister chosen by the parish. Lady Humbie made it very clear that she would not countenance the latter. Humbie's factor, Thomas Pait, had collected signatures from parishioners and heritors asking for David Howiesone, rather than Robert Elliott, to proceed to his trials in Crichton. Anticipating Humbie's petition, and likely after much jockeying for position behind the scenes, the Synod immediately welcomed another counterpetition from Penman's moderate backers. Gideon Penman was present at the meeting and, following the registration of Lady Humbie's petition, he presented a counter petition 'subscryved be severall of the heretors, elders and parochiners of the paroche of Creichtoun' requesting that the Synod confirm Robert Elliott as Penman's assistant. ${ }^{108}$ While the signatories of the petition are not mentioned, it is safe to assume they included Martin Grindlay on behalf of Lauderdale, Wauchope of Cakemuir and Archibald Weddell.

The lack of a clear ecclesiastical settlement immediately after the Restoration of monarchy ensured that the Protesters continued to agitate through the established channels of ecclesiastical dissent. John Sinclair protested that Penman had illegally received the rents of Cakemuirhill and Carberryhill (both held by the Wauchops of Cakemuir) during the time of his suspension, while James Bartrum entered a separate petition. ${ }^{109}$ It is highly likely that these petitions were orchestrated for maximum impact in a similar way to the protests in 1659. The moderates' renewed attempts to unite with Protesters meant that they were more

\footnotetext{
${ }^{107}$ NRS, CH2/252/4, f. 56.

${ }^{108}$ NRS, CH2/252/4, ff. 57-8.

${ }^{109}$ NRS, CH2/252/4, f. 67.
} 
willing to compromise than during the previous year. In May 1660, the Committee reported that it had carefully considered ratifying the election of Robert Elliot as assistant to Gideon Penman at Crichton but speculated 'whither it be convenient to lay aside all the thrie young men that have preached alreadie' and to 'doe every thing that may conduce for the peace of that paroche'. ${ }^{110}$ The most revealing detail of the Synod's more lenient attitude was that it delegated the business to a separate committee charged with uniting the Presbytery of Linlithgow, a judiciary that had been split into rival Protester and Resolutioner presbyteries since 1652 .

National politics intervened before the Synod's efforts could achieve any meaningful resolution. The Protesters' fortunes were closely aligned with the Cromwellian regime and, accordingly, the Restoration of monarchy resulted in them being marginalised. ${ }^{111} \mathrm{In}$ November 1660, Penman petitioned the Synod of Lothian and Tweeddale 'to interpone with those who are enteressed that that part of his stipend which is resting dureing the tyme of his suspension from the ministrie might be given him'. ${ }^{112}$ The Synod accepted his petition on the condition that he continued to offer five hundred merks of his stipend for an assistant. His request was given parliamentary backing the following year when an act was passed describing:

That after long process by some malicious persons against the said $\mathrm{Mr}$ Gideon before the synod of Lothian, he was suspended for the same and that, albeit he has long since returned to his ministry at the said church...nevertheless the said Elizabeth Johnston, lady Humbie, still keeps from [him] four years stipend bygone resting to them, namely $1657,1658,1659$ and 1660 , and refuses to pay the same. ${ }^{113}$

Members agreed that Penman should receive the arrears of the stipend of 1658/9 'notwithstanding he was suspended'. ${ }^{114}$ The restoration of episcopacy in September 1661 ensured that the Protesters would not be given a favourable hearing in presbyteries and their most vocal mouthpiece in Dalkeith, John Sinclair, was eventually forced into exile. The records at the point of the restoration of episcopacy are poor in quality but they suggest that a

\footnotetext{
${ }^{110}$ NRS, CH2/252/4, f. 67.

111 Julia M. Buckroyd, 'Bridging the gap: Scotland 1659-1660', Scottish Historical Review, 66 (1987), 1-5.

112 NRS, CH2/252/4, f. 83.

${ }^{113}$ RPS, $1661 / 1 / 121$.

${ }^{114}$ RPS, 1661/1/121.
} 
new election for a helper for Gideon Penman never took place. Penman continued in office until 1675.

In addition to being able to identify a highly organised group of Protesters seeking to influence the ministry in Crichton, Resolutioners were equally adept at waging a highly effective campaign of agitation to protect their influence in the parish and across the region. Historians assessing the ecclesiastical politics of the 1650s have focused a great deal of their attention on the printed polemical exchanges between Protesters and Resolutioners but the debate in Crichton produced no known printed material. While printed output was critical to the theoretical debate over Church membership, the most profound way in which the divisions in the Kirk were experienced locally was through the process of petition and counter petition we have observed in Crichton.

\section{Conclusion}

In the aftermath of the 1652 General Assembly, those who protested against the General Resolutions did not all secede from structures of the Kirk. While they may have come close to rejecting a mixed Church in theological terms, in practice most saw themselves as the rightful, if marginalised, reformers of the Kirk. The rhetorical and financial efforts made by Crichton's godly circle to affect the ministry of their parish reflects a deep commitment to the idea of a national Church. Despite the ideological splits that came to the surface in the Church in the $1650 \mathrm{~s}$, the idea of a single, national, ecclesiastical body 'continued to bind both parties'. ${ }^{115}$ Heritors had a vested pecuniary interest in maintaining the unity of the Church.

The godly commitment to a national Church was characterised by the use of aggressive legal tactics — including synchronising civil law suits with ecclesiastical complaints - to wage a war on multiple fronts against the local incumbent. The godly elite had developed an intricate understanding of how ecclesiastical and civil courts worked over the previous two decades and used their knowledge to exert maximum local pressure. This reflects the extent of powerful lay influence in the Protester movement and the ways lay and clerical Protesters cooperated. ${ }^{116}$ While further research is needed into other areas of Scotland to assess the extent of such complex godly agitation, it is unlikely that the

\footnotetext{
${ }^{115}$ Ian B. Cowan, The Scottish Covenanters 1660-1688 (London, 1976), 31.

${ }^{116}$ Holfelder, 'Factionalism in the Kirk', 297-8.
} 
Crichton/Midlothian godly elite was unique in its use of these tools, even if their level of expertise was likely unparalleled elsewhere.

By investigating papers from both civil and ecclesiastical courts, scholars can see a much wider field over which clerics could interact with their parishioners. Ministers like Penman could be involved in a wide range of civil litigation that would invariably affect their parochial ministry, but the fragments of such exchanges are rarely, if ever, mentioned in ecclesiastical records alone. Such exchanges were critical in shaping the content and nature of religious disputes well beyond 1660 but also reflect an underappreciated aspect of the ministry in pre-Restoration Scotland. Scholars seeking to understand the ways in which ministers interacted with their congregations - especially at such politically-charged junctures as the Interregnum and Restoration - must understand civil as well as ecclesiastical judiciaries.

Moreover, while the divisions within the Kirk of the 1650s manifested themselves most prominently in print, the local experience of the Protester/Resolutioner debate was characterised by handwritten petitions and counterpetitions that were aimed at a much narrower audience. This reveals a more complex 'Covenanted public' than we have hitherto assumed in which some aspects of debate were deliberately shaped for a private, highly specialised, audience. ${ }^{117}$ Nevertheless, these handwritten and largely private documents created significant amounts of local intrigue that had a greater impact on day to day parish life than battles against liberty of conscience that so liberally appeared in printed polemics of the time. Petitioning was a hallmark of parish life in the 1650s that formed the basis of arguments between Presbyterians after the Restoration. ${ }^{118}$ All of this agitation centred around who had the right to reform the one, true, national Church without ceding from it.

${ }^{117}$ Laura A. M. Stewart, Rethinking the Scottish Revolution: Covenanted Scotland, 1637-1651 (Oxford, 2016), 30 .

${ }^{118}$ Alasdair Raffe, Cultures of Controversy: Religious Arguments in Scotland, 1660-1714 (Woodbridge, 2012). 